\title{
THE PART-TIME WAGE PENALTY: DOES BARGAINING COVERAGE OUTWEIGH REGIONAL DIFFERENCES IN SPAIN?
}

\author{
Raul Ramos (AQR-IREA, UB) \\ Esteban Sanromá (IEB \& UB) \\ Hipólito Simón, (U Alicante, IEB)
}

\begin{abstract}
The use of part-time jobs is steadily increasing in most advanced economies. Previous literature has concluded that part-time workers suffer a wage penalty, but its magnitude varies across studies and countries. The part-time penalty is the otherwise unexplained element of the gap between full-time and part-time hourly earnings. One potential factor accounting for international differences in this penalty is the coverage of collective bargaining. This article outlines research examining wage differences between part-time and full-time male and female workers in Spain, a country with a very high level of coverage of collective agreements but very heterogeneous regional labour markets. Results are obtained using an econometric decomposition specifically adapted to matched employer-employee data. They show that intra-firm wage differentials for part- and full-time workers with the same characteristics are negligible. But results that are perhaps less expected are those based on the regional analysis - an unprecedented perspective compared with the previous literature. These results show that despite very significant differences in economies and labour markets, observed wage gaps between part-time and full-time workers in each Spanish region are also mainly explained by different endowments of individual, job and firm characteristics. Overall, our evidence highlights the over-riding role of wage setting mechanisms, specifically collective bargaining coverage, in minimising inter-regional differences in the wage penalty of part-time workers.
\end{abstract}

JEL Codes: J31, J22, J41, R23

Keywords: Collective bargaining, part-time work, regional differences, Spain, unexplained wage penalty, wage gap. 


\section{Introduction}

The number of part-time jobs has increased slightly but continuously in most advanced economies over the last decades. The ratio over total employment of part-time workers in the OECD increased from $13.9 \%$ in 1988 to $17.1 \%$ in 2013. Driving this type of employment are demand factors, such as the increasing importance of the service sector and fixed costs per employee, but also supply factors, like increasing women's labour participation (Euwals and Hogerbrugge, 2006; Montgomery, 1988). Furthermore, many governments have seen part-time jobs as a way of responding to economic crisis and have propelled their growth, given that they offer greater flexibility to firms in the use of their labour force while at the same time facilitating job creation.

Part-time employment is usually considered as a component of the secondary labour market that grants flexibility to firms while providing opportunities for workers with low qualifications or less closely linked to employment. However, the international literature concludes that part-time workers suffer a wage penalty that differs across countries, probably owing to differences in the wage determination process and the characteristics of collective bargaining. In fact, in countries with lower coverage of the collective bargaining, the wage penalty is usually higher. The part-time wage penalty is defined as that proportion of the raw gap between the hourly wage of full-time and part-time employees that is not explained by other factors such as worker, job, firm or regional characteristics.

Figure 1 shows a clear relationship between the wage penalty found by different studies (summarised below) and the coverage of collective bargaining in the considered countries. Taking this into account, the objective of this paper is two-fold: first, to analyse the existence (or not) of a wage penalty for part-time workers in the Spanish labour market; second, to check if there are differences in the penalty between Spanish regions. According to the previous exposition, our hypothesis is that, due to the high coverage of the collective bargaining, the wage penalty for parttime workers would be reduced and, moreover, if the size of this penalty is mainly driven by differences in labour market institutions related to collective wage bargaining, relevant regional differences would not be observed.

We begin by comparing changes in the incidence of part-time employment in Spain and Europe, and by providing analysis of the Spanish regulatory framework and regional diversity, establishing the rationale for the investigation. A review of the relevant literature then provides the conceptual tools used to analyse the contribution to the size of the part-time wage penalty of collective bargaining coverage, relative to other factors. The fourth section presents the database and the econometric methodology. The fifth section outlines the findings, and the last section summarises the conclusions of the analysis.

\section{Context and rationale}

In Spain, although the incidence of part-time employment has traditionally been low (it increased from $4.2 \%$ in 1987 to $6.8 \%$ in 1995), it accelerated over more recent decades (10.8\% in 2007 and $15.7 \%$ in 2015), propelled by a legal change approved in late 2013 allowing more flexibility in the number of working hours (IMF[International Monetary Fund], 2015). The recent economic crisis has represented a significant loss of jobs in Spain. Between 2008 and 2014, more than three million jobs (15\% of 2008 employment levels) were destroyed. However, during these years the number of part-time jobs increased by more than 350,000 people (a $14.7 \%$ increase over a six year period) (INE [Instituto Nacional de Estadística], 2016).

From an international perspective, the share of part-time workers in Spain is still a moderate figure, lower than the averages for the OECD [Organisation for Economic Cooperation and Development] (17.1\%), the EU [European Union] (19.6\%) and the Eurozone (21.5\%) averages. The traditionally low presence of part-time jobs in Spain is probably explained because 
its regulation has not been clear until very recently (Muñoz de Bustillo et al., 2008; FernándezKranz and Rodríguez-Planas, 2010), but also because Spanish firms have usually tended to achieve flexibility mainly through fixed-term contracts. On the other hand, it must be noted that a prominent characteristic of part-time employment in Spain is that, in contrast to most developed countries, it is mainly involuntary. Thus, according to Eurostat (2016a) figures for 2014, a 64\% of total part-time work in Spain was involuntary (70\% for men and $62 \%$ for women), whereas the averages for the OECD, the European Union and the Eurozone were 21\% (23\% for males and $20 \%$ for females), $29 \%$ (40\% for males and 26\% for females), and 32\% (42\% for males and 29\% for females) respectively.

Even though largely involuntary, part-time employment in Spain is on the whole highly regulated. The Spanish labour market follows the so-called Mediterranean model (Sapir, 2005). Union density is relatively low (16\%), but the coverage of collective agreements is very high, close to $80 \%$ (ILO - International Labour Office, 2015), as a result of the legal extension of collective agreements. Sectoral collective bargaining predominates, covering the $90 \%$ of employees covered by agreements, while firm level bargaining represents only $10 \%$, although it has been clearly promoted by the 2012 labour reform. Regarding sectoral bargaining, although there are national sectoral collective agreements that apply throughout the Spanish territory, most sectoral agreements are negotiated at regional (NUTS [Nomenclature of Units for Territorial Statistics] 2 level) or, especially, provincial levels (NUTS 3). These agreements apply to all companies and workers in the sector and territory, so that the coverage of collective bargaining is in general very high in all Spanish regions. The minimum wage accounts for $36 \%$ of the average wage, Spain being one of the advanced countries with the lowest percentage together with the United States, Estonia and the Czech Republic. However, Spain is the European country with the lowest percentage $(0.2 \%)$ of workers earning less than $105 \%$ of the minimum wage (Eurostat, 2016b).

Wage differentials in Spain have traditionally been small, as in most continental Europe countries, due to the high coverage of collective agreements. However, during the crisis, wage inequality in Spain increased due to the wage devaluation suffered by those workers who have had to change jobs during the last years, mostly temporary workers (Font et al., 2015). After Poland, Spain is the second European country with the largest presence of temporality (26\% of employees) (Eurostat, 2016a). This high figure is usually explained by the characteristics of the Spanish productive structure, with a high specialisation in activities such as services and construction, and the high costs of firing permanent workers (Jaumotte, 2011).

The employment rate of Spanish women is $50 \%$, ten points below men and nine points below the employment rate for European women. However, women now represent $45 \%$ of the total Spanish employment. Female workers are predominant in several service activities (retail, hospitality, health and other services) and in two manufacturing sectors (clothing and the pharmaceutical industry) (INE, 2016). We will thus analyse wage penalisation for part-time workers in the Spanish labour market, distinguishing among men and women.

Spain's recent increasing trend in part-time employment, which will probably continue in the future, together with the mainly involuntary nature of this type of employment, clearly justifies interest in analysing the main characteristics of part-time jobs in Spain, including wages. Although economic theory gives reasons to expect a wage penalisation for part-time employees, and previous studies for other countries show that this is a stylised fact in the labour markets of other advanced countries, research on the Spanish case is rather scarce and inconclusive, which justifies interest in advancing knowledge of the consequences of part-time employment for wages in this economy. Moreover, owing to the high coverage of collective bargaining in Spain (close to 80\%), we expect that the size of the wage penalty associated with part-time work will be relatively low.

Next, we carry out a regional analysis of the wage penalty for part-time workers - as far as we know, a novel approach in the international literature. The Spanish case is especially attractive from this perspective, given that regional differences in the incidence of part-time 
employment are rather important, and observed wage differences between part-time and full-time workers also exhibit a significant regional heterogeneity. In Spain, regional labour markets and regional economies have traditionally exhibited very important differences, including unemployment rates (López-Bazo et al., 2005; Bande et al., 2008) and demographic trends. For instance, while some regions concentrate most of the population, in others it is dispersed (Ayuda et al., 2010; Goerlich and Mas (2008). The regional capacity to attract foreign workers has also been unequal (González and Ortega, 2011), while internal migratory flows have remained subdued (Bentolila, 1997). As discussed by Cuadrado-Roura and Maroto (2016), clear specialisation patterns are present in Spanish regions. While some regions such as Madrid, the Basque Country, Navarre and Catalonia are specialised in manufacturing and market services, the rest of regions are mainly specialised in construction, non-commercial services and energy and primary services activities. These industries have higher sensitivity to business cycles and suffered more during the last recession. R\&D activities and innovative capacities are also geographically concentrated in a few regions (Coronado and Acosta, 1997). The high level of decentralisation (according to the IMF Government Finance Statistics Yearbook 2010, the sub-national share in total government expenditure is $48 \%$ and regional authorities are responsible for active labour market policies) is another distinguishing feature of the Spanish political system that has to be taken into account in this context.

All in all, the nature of the wage differentials observed between full-time and part-time workers, together with the structural differences between Spanish regions and their labour markets and the high coverage of wage bargaining, make the analysis particularly interesting. While high bargaining coverage suggests that differences in regional wage penalties will be reduced, the high level of regional heterogeneity casts some doubts about this prediction. Taking into account that there are no previous studies looking at the regional dimension in this context, our analysis tries to provide novel evidence regarding which forces predominate in the process of wage determination. Our empirical analysis for the Spanish economy relies on the use of an employeremployee dataset, the Spanish Encuesta de Estructura Salarial (Survey of Earnings Structure; hereafter SES). The use of such matched employer/employee data is rare in most previous studies in the topic (some exceptions can be found in Mumford and Smith, 2008 and O'Dorchai et al., 2007). Moreover, an econometric decomposition specifically adapted for use with this kind of data that allows controlling for the effect of unobserved firm heterogeneity on wages is employed.

\section{Literature review}

Part-time employment is usually seen as another component of the secondary labour market that grants flexibility while providing employment for persons with low qualifications or less closely linked to the labour market (students or young adults, women limited by familial responsibilities, advanced age adults or those approaching retirement, among others). The characteristics usually associated with part-time jobs include lower wages, high temporality and, in the case of certain countries or modalities of partial employment, fewer worker rights (such as paid holidays, remuneration for medical leave or firing costs). Part-time employees are presented as having: reduced access to social security benefits (Houseman and Matchiko, 1998); fewer labour progress opportunities (Tilly, 1990; Russo and Hassik, 2008); smaller pensions (Ginn and Arber, 1998; O'Connell and Gash, 2003); less labour stability (Muñoz Bustillo et. al., 2008; Fernández-Kranz et. al., 2014); and a lower unionisation rate (Belous, 1988).

The issue that has garnered the most attention of researchers is the study of wage differences. The stylised facts of this international literature (Table A1) suggest that there is in general a negative wage difference (in terms of hourly wage) for part-time employees when 
compared to full-time employees ${ }^{1}$ and that part of this raw wage gap is explained by differences between each group in worker characteristics, whether observable or unobservable. Moreover, the characteristics of the job and the firm contribute to explaining the wage differential significantly, given that many part-time workers are engaged in low-wage occupations, industries, and firms (Hirsch, 2005, among others). However, despite adding multiple explanatory factors, an unexplained part of the wage differential usually persists, which is considered the wage penalty associated with working part-time. This wage penalty could be null for young people accessing their first job (Russo and Hassik, 2008), while there is abundant evidence that the differential increases with age and especially with years worked in part-time positions (Wolf, 2014) and that wage increases over time are also lower for part-time workers (Fernández-Kranz and RodríguezPlanas, 2011). While abundant gender analyses agree that the wage penalty is usually greater for women than for men, studies making disaggregated estimations are scarce. Studies disaggregating by levels of qualification conclude that the wage penalty is greater for the most qualified workers, as they suffer more from the effects of occupational degradation (Connolly and Gregory, 2009). Empirical evidence differentiating by labour market segments finds that the wage penalty is almost entirely due to the concentration of part-time employment in the secondary labour market (O'Connell and Gash, 2003). On the other hand, studies with regional disaggregation have rarely been conducted. Only two previous studies examine a territorial level lower than the national level: Harris (1993) examines the issue for women in Northern Ireland, finding a penalty of 19\%, and Wolf (2014) distinguishes between West and East Germany, obtaining similar results for both parts of the country.

Studies for the Spanish economy are rather scarce and present very dissimilar results, so additional evidence is needed. A first generation of papers, working with the European Community Household Panel (ECHP) estimate positive wage premiums for both genders, whether controlling or not for self-selection with probits (Cebrián et al., 2000, Pissarides et al., 2005; Pagán, 2007). More recently, using data from the Continuous Sample of Working Histories (MCVL in Spanish), Fernández-Kranz and Rodríguez-Planas (2011) obtain (for 25 to 45 year-old women only) a wage penalty of 11.4 points, controlling for occupations and adding firm fixed effects. In more recent work with the same database, Fernández-Kranz et al. (2014) estimate that part-time women aged 23 to 45 have wage penalties of -6.1 logarithmic points if they have indefinite contracts and of -9.0 points if the contract is temporary.

\section{Data and methodology}

\subsection{Data}

This research is based on cross-section microdata from the most recent available wave of the SES, corresponding to 2010. The SES is a nationally representative survey on firms, covering employees at establishments of any size. It encompasses the bulk of the Spanish private sector, excluding only specific industries such as agriculture and domestic service.

Because the survey design is based on a two-stage sampling of employees working in firms, one of its most important features is the inclusion of matched employer-employee microdata. Moreover, it provides information about each of the 17 Spanish regions in which surveyed establishments are located, allowing for regional analysis which is a central part of this research.

\footnotetext{
${ }^{1}$ However, in countries like Australia and South Africa, a positive wage bonus for part-time workers is observed (Posel and Muller, 2007 and Booth and Wood, 2008).
} 
The survey provides detailed information on wages and characteristics of workers, jobs and firms. Workers are classified as part-time or full-time according to the information provided by the firm. The wage concept used in this research is the gross hourly wage and in its calculation any payment by companies that has been incorporated. The analysis is carried out separately for men and women. The explanatory variables considered include characteristics of individuals and attributes of their jobs and firms. The former are controls relating to: the nationality of the individual (i.e. differentiating between Spaniards vs. non-Spaniards); the level of general education (primary, secondary, or tertiary education); and age. The characteristics of the job are: years of seniority in the current job (including its quadratic form); type of contract (indefinite or fixed-term); and occupation (unskilled, semi-skilled or skilled occupations), while attributes of the firms are: industries of activity (12 categories); size (four categories); type of collective agreement (firm, national sector, or sub-national sector agreements); and region of location of the firm.

The SES has some advantages over other surveys also used in the analysis of wage differentials between part- and full-time workers for the Spanish case, such as the MCVL. Although the MCVL presents a larger size and contains highly reliable administrative registers and longitudinal information, the SES contains matched employer-employee data that provide rich information on different variables that are crucial in explaining wage differentials and do not suffer from severe measurement error in the MCVL (namely educational level and occupation). Moreover, unlike the MCVL, the SES contains uncensored wages without maximum and minimum limits, and includes information regarding the number of hours worked, permitting the use of hourly wages as dependent variable.

Regarding potential limitations of the dataset, note that with the SES it is not possible to take into account in the empirical analysis the potential selection bias associated with the selection of working part- or full-time by individuals. The usual form to correct this problem, apart from being controversial, requires the use of valid exclusion restrictions that are not available in the SES. However, the fact that most part-time employment in Spain is involuntary reduces the scope of this limitation in the Spanish context. In any case, the potential impact in our results of not being able to control for selection bias cannot be easily assessed. In the light of the results obtained in the available studies, it is extremely difficult to assess the effect of not controlling for selfselection. No clear pattern emerged from the literature review: in some papers, after controlling for self-selection, the wage penalty is reduced; in others, there is no effect or the penalty even increases.

Observations with missing values on key variables and those for individuals aged less than 16 years or over 65 years have been filtered. As most previous studies on the relative wage treatment of part-time workers limit the analysis to private sector employees, observations corresponding to the public sector have been removed. The final sample is formed by 152,099 observations, 89,344 men and 62,755 women, and the regional samples range between 2,152 and 28,382 employees. The descriptive statistics of the samples can be consulted in Table A.2.

\subsection{Methodology}

In the empirical analysis, we use an extension of the Juhn et al. (1993) decomposition, specifically adapted for use with matched employer-employee data. This technique departs from the estimation of the following semi-logarithmic wage equation:

$$
w_{i j}=X_{i} \beta+\varepsilon_{i j}+a_{j}
$$

wherein: $w_{i j}$ is the natural $\log$ of hourly wage of individual $\mathrm{i}$ in workplace $\mathrm{j} ; X_{i}$ is a vector of controls including individuals' characteristics and those of their jobs and the firms employing them; $\beta$ is a vector of parameters to be estimated (including an intercept); $\varepsilon_{i j}$ is a stochastic error term; and $a_{j}$ is an error component corresponding to workplace $\mathrm{j}$ and invariant for all individuals working in the same workplace. 
Following the recommendation of Oaxaca and Ransom (1994) and Neumark (1998), as a first step of our decomposition analysis, equation (1) is estimated for the pool of workers (i.e., full- and part-time workers). Identification of workplace effects is guaranteed, given that there is more than one observation per workplace in the dataset. Since the result of Hausman's contrast indicates that workplace-specific effects are correlated to the rest of the explanatory variables in equation (1), the model is estimated by fixed effects (which is equivalent to estimating by ordinary least squares with a set of workplace dummies). Relying on the properties of the ordinary least squares estimator, after the estimation of equation (1) with the pooled data, the average wage of the subgroup of workers $\mathrm{s}$ ( $\mathrm{s}=$ full- or part-time workers) can be expressed as:

$$
\bar{w}^{s}=\bar{X}^{s} \hat{\beta}+\sigma \bar{\theta}^{s}+\eta \bar{\lambda}^{s} \quad \text { where } \bar{\theta} \sim(0,1), \quad \bar{\lambda} \sim(0,1)
$$

where: $\bar{w}^{s}$ stands for the mean natural log of the hourly wage of a given group $\mathrm{s} ; \bar{X}^{s}$ is a vector of the average of the set of explanatory variables for group $s ; \hat{\beta}$ is the vector of coefficients estimated with equation (1) and the pooled data; $\sigma$ is the estimated standard deviation of wage residuals of the pool of workers; $\bar{\theta}^{s}$ is the average standardised residual of group $s ; \eta$ is the estimated standard deviation of workplace effects of the pool of full- and part-time workers; and $\bar{\lambda}^{s}$ is the average standardised workplace effect of group $\mathrm{s}$.

Using the pooled wage structure as the market price reference in the decomposition, the wage gap between part- and full-time workers can be written as follows:

$$
\bar{w}^{p}-\bar{w}^{f}=\left(\bar{X}^{p}-\bar{X}^{f}\right) \hat{\beta}+\left(\bar{\theta}^{p}-\bar{\theta}^{f}\right) \sigma+\left(\bar{\lambda}^{p}-\bar{\lambda}^{f}\right) \eta=\Delta \bar{X} \hat{\beta}+\Delta \bar{\theta} \sigma+\Delta \bar{\lambda} \eta
$$

Where: the subscript $p$ is for part-time workers and $f$ is for full-time workers; and a $\Delta$ prefix denotes the average difference between both groups in the subsequent variable.

In brief, equation (3) provides a decomposition of the part-time/full-time wage gap that quantifies the extent to which average wage differences between part-time and full-time workers are related to: (a) differences in observed characteristics $\left(\bar{X}^{p}-\bar{X}^{f}\right)$, valued at market prices $(\hat{\beta})$; (b) the influence of unobserved elements measured as the impact of differences between part- and fulltime workers on the average standardised residual $\left(\bar{\theta}^{p}-\bar{\theta}^{f}\right)$ multiplied by the money value per unit difference in the standardised residual $(\sigma)$, which determines the specific wage penalty suffered by the disadvantaged group; and (c) the influence of workplace-related factors, namely the product of the difference in the average standardised workplace effect of part- and full-time workers $\left(\bar{\lambda}^{p}-\bar{\lambda}^{f}\right)$, which measures the intensity of part-time workers' segregation into low-wage workplaces, and the dispersion of wage differentials across workplaces $(\eta)$, which determines the degree of the wage penalty for part-time workers resulting from this segregation. Note that the second term of the decomposition corresponds to an estimation of the average intra-firm wage differential in the Spanish economy between part- and full-time employees with the same observed characteristics and working in the same firm.

\section{Results}

Table 1 provides information on the wage differential between part- and full-time workers (measured as the logarithm of the wage per hour) and on the incidence of part-time work for Spain and the Spanish regions, distinguishing between male and female workers. A negative (positive) wage differential corresponds to a wage disadvantage (advantage) of part-time workers, whereas the incidence of part-time is measured on the total number of employees. This evidence shows that in Spain there is a significant negative average wage differential for part-time workers, with 
a gap substantially lower in the case of men (-0.104 logarithmic points) than of women $(-0.254$ logarithmic points), and that the incidence of part-time employment is much higher in the case of women $(27.7 \%$ of total employees) than of men $(8.7 \%)$, as is usual in most advanced economies.

Table A.2 contains the descriptive statistics for the samples used in the analysis. ${ }^{2}$ They reveal significant differences in observed characteristics of full- and part-time workers in Spain, which tend to be in general detrimental for part-time workers' wages. So, without being exhaustive, the comparison between the characteristics of full- and part-time workers reveals that, for both genders, the latter have on average lower endowments of education (and of seniority in the firm just in the case of females); higher incidence of immigrants and temporary contracts; greater presence in occupations associated with lower levels of qualification and in construction and, especially, services; and, finally, greater representation in smaller firms and firms covered by sectoral agreements (the latter being true only in the case of females). Conversely, part-time workers only exhibit better relative endowments of age, and just in the case of males.

On the other hand, the magnitude of the average wage differential associated with parttime work exhibits a significant regional heterogeneity, and regional differences in the incidence of part-time employment are also rather important (Table 1). Regarding the former, in the case of female workers the magnitude of the differential exceeds the national average in regions like Andalusia, Extremadura, or Madrid, whereas in others like Navarra or The Rioja the differential is notably lower (the maximum and minimum values of the wage differential are $-0.315 \log$ points for Extremadura and -0.071 for The Rioja, with a standard deviation of 0.071, and all the wage differentials estimated for Spanish regions are statistically significant at conventional levels). Regional differences are in general also important in the case of male workers (with an extreme value of the differential of $-0.299 \mathrm{log}$ points for Madrid and a standard deviation of 0.100 ), although in this case wage differentials are not statistically significant for most regions. With regard to the incidence of part-time employment, as a matter of example among men the percentage of part-time workers in the Canary Islands (11.1\%) doubles that of Asturias (5.5\%), while among women, Navarra (31.4\%) is ahead of Madrid $(20.8 \%)$ by eleven percentage points.

The results of applying the extension of the Juhn et al. (1993) methodology for the decomposition of the differentials in average wages between part-time and full-time workers in Spain are shown in Table 2, distinguishing between males (left panel) and females (right panel). In particular, the first row of the table shows the value of the raw differential in log hourly wages between the two groups of workers, while the rest of the rows show the value of the different terms of the decomposition (where a negative value indicates that the factor has a negative effect on the relative wages of part-time workers). For each case, we consider four specifications of the wage equation (1). The first specification (model 1) includes only explanatory variables related to the socio-demographic characteristics of the individuals (i.e. nationality, education and age). The second specification (model 2) includes the same individual characteristics along with characteristics related to job and firm (seniority, type of contract, region, industry, size and type of collective agreement). The third specification (model 3) includes also categorical variables for occupation. ${ }^{3}$ The last specification (model 4) includes firm fixed effects instead of observed firm characteristics and thus allows controlling for the effect on wages of unobserved firm heterogeneity. The results of models 1 to 3 are equivalent to those that would be obtained from a standard decomposition in two components (characteristics and returns) à la Oaxaca-Blinder,

\footnotetext{
${ }^{2}$ To conserve space, they correspond to the whole samples for the overall Spanish economy. Descriptive statistics of the samples for every Spanish region are available from the authors on request.

${ }^{3}$ The reason for separating out this variable in the analysis is that it potentially suffers from endogeneity in relation to the distribution of individuals between full- and part-time jobs, to the extent that part-time employment is often limited to low-wage occupations (see, eg Manning and Petrongolo, 2008).
} 
whereas results from model 4 also include the third component of the right side of the equation (3).

The results of model 1 reveal that when only individual characteristics are considered, the lower wage levels of part-time workers cannot be explained by their relative endowments of characteristics, but essentially by a different wage treatment. In the case of male workers, the component associated with characteristics takes a negligible value of $0.002 \log$ points — not significantly different from zero - while most of the origin of the wage differential $(-0.104)$ corresponds to the unexplained part (-0.106). In the case of female workers, observed individual characteristics explain a relevant part of the differential $(-0.104 \log$ points or around $41 \%$ of the raw gap), but again most of the differential $(-0.254)$ is related to the unexplained part $(-0.150)$. Overall, this evidence suggests that when considering just individuals with the same sociodemographic observed characteristics, the average part-time wage-penalty in the Spanish labour market is of -10.6 logarithmic points for males and of -15.0 points for female workers.

The inclusion of additional explanatory variables related to the characteristics of jobs and firms (model 2) substantially increases the contribution of the explained component for both genders. In the case of male workers, lower educational levels and seniority, a higher incidence of fixedterm contracts and a higher presence in low-wage industries arise as relevant explanatory factors of the wage disadvantage of part-time male workers, whereas the factor with a more significant positive effect for this group is their higher relative age. ${ }^{4}$ For female workers, the factors explaining lower wages of part-time employees are also related to lower endowments of education and seniority and higher presence in low-wage industries. Nevertheless, the most remarkable result of the evidence obtained from model 2 is that, in contrast with results with model 1 , a very important part of the wage gap between part-time and full-time workers is now explained: the contribution of the explained part of the differential increases to $66 \%$ of the raw gap for men and to $82 \%$ for women. The unexplained part (or wage penalty) is of only $-0.036 \mathrm{log}$ points for men and $-0.046 \log$ points for women, representing $35 \%$ and $18 \%$ of the total gap, respectively. When including also occupation as an explanatory variable (model 3), occupational segregation arises as a very relevant explanatory factor of the wage gaps between full- and part-time workers, very especially for females ${ }^{5}$ (this factor alone explains $0.053 \mathrm{log}$ points or $51 \%$ of the gap for males and $0.116 \log$ points or $46 \%$ for females); although the rest of the results are overall rather similar, the unexplained components of the decomposition almost halves for both males (-0.016) and females (-0.024). These latter values are very different from the wage premium for part-time workers previously found for Spain by Cebrián et al. (2000), Pissarides et al. (2005), and Pagán (2007) using the ECHP, but are close to the results obtained by O'Dorchai et al. (2007) with the 1995 SES for men (-0.06 log points), and lower than those obtained by Fernández-Kranz and Rodríguez-Planas (2011) and Fernández-Kranz et al. (2014) using the MCVL (between -0.06 and $-0.13 \log$ points) and a similar set of explanatory factors. It is worth mentioning that the estimated penalty according to model 3 (with similar controls to those included in the models summarised in figure 1) is very close to the one expected when regressing the wage penalty on the coverage of collective bargaining: around 4 percentage points. This result is another sign of the importance of this variable to explain cross-country differences in the wage penalty of part-time workers.

\footnotetext{
${ }^{4}$ This finding is consistent with the fact in Spain a significant part of job contracts among part-time male workers is related to partial retirement (Muñoz de Bustillo et al., 2008).

${ }^{5}$ Obtained evidence suggests that the specific contribution to the full-time/part-time wage gap of certain variables such as industry and, especially, occupation is much higher in the case of females than in the case of male workers. The main reason is that part-time females are significantly segregated into low-wage occupations and industries (Table A.2) (Sage: hyperline and print-version inclusion of URL, a finding that is consistent with the fact that occupation and industry segregation are very relevant determinants of female relative wages everywhere (see, e.g., Ponthieux and Meurs, 2015).
} 
The relevance of differences in characteristics as the main explanatory factor of the wage differential between part- and full-time workers is reinforced when observed firm level variables are replaced by firm fixed effects (model 4). According to this additional evidence, for both genders the wage disadvantage of part-time workers is almost fully explained now by their relative endowments of individual and job characteristics (the first term of the decomposition explains $31 \%$ of the raw gap for men and $57 \%$ for women) and, especially, by their relative segregation in low-wage firms (according to the second term the unequal distribution by firms of part- and fulltime workers explains $69 \%$ of the gap for men and $42.5 \%$ for women). As a consequence, the third component associated with the wage residuals has a minimum influence to explain the gap: actually, it is not statistically different from zero both for male and female workers. Given that this term is an estimation of the average intra-firm wage differential between part- and full-time employees with the same characteristics, this last result shows that part- and full-time workers who possess the same observed characteristics and who work in the same type of job (including occupation) and in the same firm overall tend to receive a similar wage treatment in the Spanish labour market (i.e., there is no evidence of direct wage discrimination). This result is consistent with the high coverage of collective bargaining in Spain.

On the other hand, Table 3 shows the results of the Juhn et al. (1993) decomposition of average wages between part-time and full-time workers for each of the 17 Spanish regions (the upper panel refers to males and the lower panel to females) corresponding to model 4 (i.e. including firm fixed-effects). The obtained results show marked differences among regions, particularly for female workers. As regards component (1) of the decomposition, differences in endowments of observed characteristics are in the case of females systematically unfavourable for part-time workers in all considered regions and they are a relevant explanatory factor for the negative wage gap for part-time female workers in almost every region, whereas for males the first component of the decomposition has positive or negative values depending on the region. As regards the effect of the second component, it is observed that both for males and females the different relative distribution of full- and part-time workers among firms tends to be a relevant explanatory factor of wage differentials in every region (this component is statistically significant for most regions, both for males and females). Finally, with a few exceptions, the values of the third component are for most Spanish regions not statistically different from zero for both males and females, so wage penalties against part-time workers are practically non-existent at regional level. Overall, this evidence suggests that in most Spanish regions the bulk of the observed wage gap between full- and part-time workers is mainly explained by their different endowments of individual, job and firm characteristics and, therefore, that the significant regional heterogeneity observed for the Spanish regions in the magnitude of the wage differential between full- and parttime employees is essentially not explained by regional specific factors. So, the absence of wage penalties to part-time workers, even in the presence of such big differences, can probably be explained by the wage determination process operating in Spain with a high level of coverage of collective agreements in all regions.

\section{Conclusions}

This article has examined wage differentials between part- and full-time workers in Spain distinguishing by gender. It has contributed to the related literature by introducing a fully novel regional perspective into the analysis and by using an econometric decomposition method that takes advantage of the use of a matched employer-employee dataset. This technique allows, inter alia, estimating intra-firm wage differentials for part- and full-time workers with similar observed characteristics as well as the impact in the part-time wage penalty of the segregation of part-time workers in low-wage firms.

The obtained evidence has shown that part-time workers in Spain experience a significant average wage disadvantage, and that this disadvantage is significantly higher for female workers. 
The results of the econometric decompositions have also shown that the wage penalty associated with part-time workers, both males and females, is almost fully explained by their relative characteristics and, in particular, by the significant segregation of part-time workers in low-wage firms. In fact, intra-firm wage differences between full- and part-time workers with similar observable productive characteristics working in the same firm are negligible for both genders, which suggests a similar wage treatment by Spanish firms of full- and part-time workers; hence, the absence of direct wage discrimination against part-time workers - a result that is probably related to the high coverage of collective agreements in the Spanish labour market.

From a regional perspective, in the case of Spain it has been observed that regional differences in the incidence of part-time employment are rather significant and that observed wage differences between part-time and full-time workers also exhibit a very significant regional heterogeneity. The empirical evidence regarding the origin of the wage differential suggests, nevertheless, that in the majority of the Spanish region, most of the observed average wage differential between part- and full-time workers tends to be explained by worker endowment factors so that wage penalties do not usually exist at a regional level. This absence of wage penalties for part-time workers supports the hypothesis that a high coverage of wage bargaining prevents discriminatory practices against part-time workers, and reinforces the idea that one of the major sources of cross-country differences in the wage penalty of part-time workers is differences in labour market institutions such as collective bargaining.

\section{Funding}

This work was supported by the Spanish Ministry of Economy and Competitiveness under grants ECO2013-41022-R, ECO2013-41310-R, 2014 SGR-420 and CSO2014-55780-C3-2-P (National R\&D\&I Plan).

\section{References}

Ayuda MI, Collantes F and Pinilla VJ (2010) Long-run regional population disparities in Europa during modern economic growth: a case study of Spain. Annals of Regional Science 44(2): 273-295.

Bande R, Fernández R and Montuenga V (2008) Regional unemployment in Spain: disparities, business cycle and wage setting. Labor Economics 15(5): 885-914.

Belous R (1989) The Contingent Economy: The Growth of the Temporary, Part-Time and Subcontracted Workforce. Washington DC: National Planning Association.

Bentolila S (1997) Sticky labor in Spanish regions. European Economic Review 41(3-5): 591-598.

Booth AL and Wood M (2008) Back-to-front down under? Part-time/full-time wage differentials in Australia. Industrial Relations 47(1): 114-135.

Cebrián I, Gash V, Moreno G, O'Connell P and Toharia L (2000) Peripheral labour in peripheral markets? Mobility and working time within transitional labour markets among women in Ireland and Spain. In: O’Reilly J, Cebrián I and Lallement M (eds) Working-Time Changes. Social Integration Trough Transitional Labour Markets. Cheltenham UK: Edward Edgar, pp. 205-250.

Connolly S and Gregory M (2009) The part-time pay penalty: earnings trajectories of British women. Oxford Economic Papers 61(S1): i76-i97.

Coronado D and Acosta M (1997) Spatial distribution of patents in Spain: determining factors and consequences on regional development. Regional Studies 31(4): 381-390.

Cuadrado-Roura JR and Maroto A (2016) Unbalanced regional resilience to the economic crisis in Spain: a tale of specialisation and productivity. Cambridge Journal of Regions, Economy and Society 9(1): 153-178.

Eurostat (2016a) Labour Force Statistics. Available: http://ec.europa.eu/eurostat/web/lfs/data/database (accessed 1 June 2016).

Eurostat (2016b) Minimum Wage Statistics. Available: http://ec.europa.eu/eurostat/statisticsexplained/index.php/Minimum_wage_statistics (accessed 1 June 2016). 
Euwals R and Hogerbrugger M (2006) Explaining the growth of part-time employment: factors of supply and demand. Labour 20(3): 533-557.

Fernández-Kranz D and Rodríguez-Planas N (2010) El contrato a tiempo parcial. Papeles de Economía Española. 124:148-163.

Fernández-Kranz D and Rodríguez-Planas N (2011) The part-time penalty in a segmented labor market. Labour Economics 18(5): 591-606.

Fernández-Kranz D, Paul M and Rodríguez-Planas N (2014) Part-time work, fixed-term contracts, and the returns to experience. Oxford Bulletin of Economics and Statistics 77(4): 512-541. http://dx.doi.org/10.1111/obes.12073.

Font P, Izquierdo M and Puente S (2015) Real Wage Responsiveness to Unemployment in Spain: Asymmetries along the Business Cycle. WP 1504. Madrid: Banco de España.

Ginn J and Arber S (1998) How does part-time work lead to low pension income? In: O'Reilly J and Fagan C (eds) Part-Time Prospects: An International Comparison of Part-Time Work in Europe, North America, and the Pacific Rim. London: Routledge, pp. 156-173.

Goerlich F and Mas M (2008) Empirical evidence of population concentration in Spain during 19002001. Population 63(4): 635-649.

González L and Ortega F (2011) How do very open economies adjust to large immigration flows? Evidence for Spanish regions. Labor Economics 18(1): 57-70.

Harris R (1993) Part-time female earnings: an analysis using Northen Ireland NES data. Applied Economics 25: 1-12.

Hirsch BT (2005) Why do part-time workers earn less? The role of workers and job skills. Industrial and Labor Relations Review 58(4): 525-551.

Houseman S and Machiko O (1998) What is the nature of part-time work in the United States and Japan? In: O'Reilly J and Fagan C (eds) Part-Time Prospects: An International Comparison of Part-Time Work in Europe, North America, and the Pacific Rim. London: Routledge, pp. 232-251.

ILO [International Labour Office] (2015) Labour Relations and Collective Bargaining. Issue Brief No 1, October. Geneva: ILO.

IMF [International Monetary Fund] (2015) Spain Selected Issues. IMF Country Report, 15/223.

INE [Instituto Nacional de Estadística](2016) Encuesta de Población Activa. Resultados detallados, Media de los cuatro trimestres. Available: http://www.ine.es/jaxiT3/Tabla.htm?t=4877\&L=0 (accessed 1 June 2016).

Jaumotte F (2011) The Spanish Labor Market in a Cross-Country Perspective. IMF Working Paper 11/11. Available: https://www.imf.org/external/pubs/ft/wp/2011/wp1111.pdf (accessed 1 June 2016).

Juhn C, Murphy K and Pierce B (1993) Wage inequality and the rise in returns to skill. Journal of Political Economy 101(3): 410-442.

López-Bazo E, del Barrio T and Artís M. Geographical distribution of Unemployment in Spain. Regional Studies 39(3): 305-318.

Manning A and Petrongolo B (2008) The part-time pay penalty for women in Britain. Economic Journal 118(526): F28-F51.

Montgomery M (1988) On the determinants of employer demand for part-time workers. The Review of Economics and Statistics 70(1): 112-117.

Muñoz de Bustillo R, Fernández E and Antón JI (2008) El trabajo a tiempo parcial en España en el contexto de la Unión Europea. Características, condiciones de trabajo y perspectivas. Ministerio de Trabajo e Inmigración, Colección Informes y Estudios, Serie Empleo n 36, Madrid.

Neumark D (1988) Employer's discriminatory behaviour and the estimation of wage discrimination. Journal of Human Resources 23(3): 279-295.

Oaxaca R and Ransom M (1994) On discrimination and the decomposition of wage differentials. Journal of Econometrics 61(1):5-22.

O'Connell PJ and Gash V (2003) The effects of working time, segmentation and labour market mobility on wages and pensions in Ireland. British Journal of Industrial Relations 41(1): 71-95.

O'Dorchai S, Plasman R and Rycx F (2007) The part-time wage penalty in European countries: how large is it for men? International Journal of Manpower 28(7): 571-603.

Pagán R (2007) Diferencias salariales entre el empleo a tiempo completo y parcial. Revista de Economía Aplicada 15(43): 5-48. 
Pissarides C, Garibaldi P, Olivetti C, Petrongolo B and Wasmer E (2005) Women in the labor force: how well is Europe doing? In: Boeri T, Del Boca D and Pissarides C (eds) Women at Work: An Economic Perspective. Oxford UK: Oxford University Press, pp. 9-120.

Ponthieux S and Meurs D (2015) Gender inequality. In: Atkinson AB and Bourguignon F (eds) Handbook of Income Distribution. Volume 2. Amsterdam: Elsevier, pp. 981-1146.

Posel D and Muller C (2007) Is there Evidence of a Wage Penalty to Female Part time Employment in South Africa? University of Kwazulu-Natal, ERSA Working Paper No 61.

Rodgers JR (2004) Hourly wages of full-time and part-time employees in Australia. Australian Journal of Labour Economics 7(2): 231-254.

Russo G and Hassik W (2008) The part-time wage gap: a career perspective. De Economist 156(2):145174.

Sapir A (2005) Globalisation and the Reform of European Social Models. Bruegel Policy Contribution. Available: http://bruegel.org/wpcontent/uploads/imported/publications/pc_sept2005_socialmod.pdf (accessed 1 June 2016).

Tilly C (1990) Short Hours, Short Shrift: Causes and Consequences of Part-Time Work. Washington DC: The Economic Policy Institute.

Wolf E (2014) The German Part-time Wage Gap: Bad News for Men? SOEP papers 663/2014. Available: https://www.diw.de/documents/publikationen/73/diw_01.c.466650.de/diw_sp0663.pdf (accessed 1 June 2016). 


\section{Figures and tables}

Figure 1.

Average unexplained component of wage differentials between part-time and full-time workers and coverage of collective bargaining.

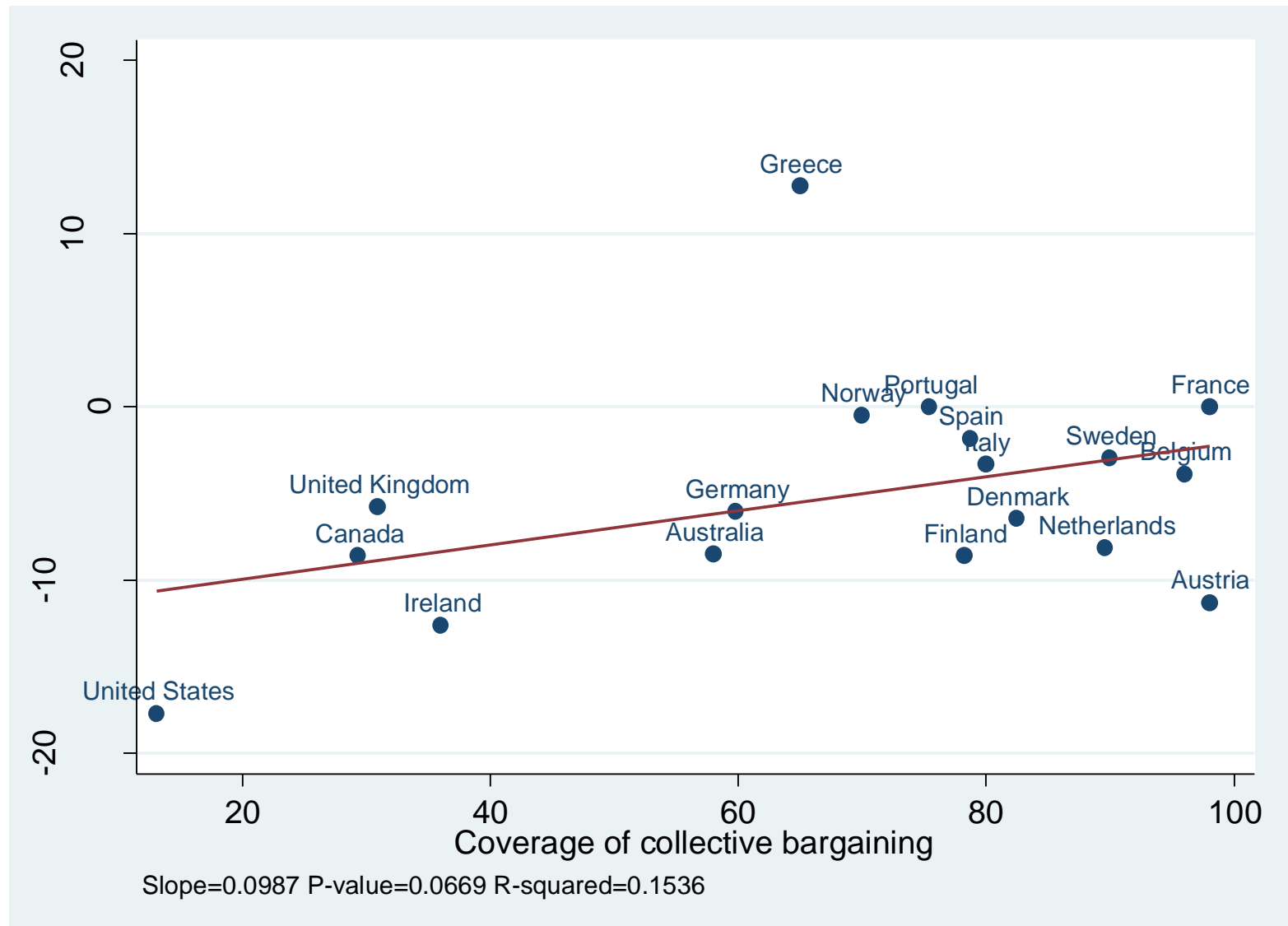

Country averages of wage penalties found in the literature for male part-time workers with similar specifications. Collective bargaining data refers to 2010 and have been obtained from ILOStat. 
Table 1.

Incidence of part-time work and wage differences between part-time and full-time workers in Spanish regions.

\begin{tabular}{|c|c|c|c|c|}
\hline & \multicolumn{2}{|c|}{$\begin{array}{c}\text { Incidence of } \\
\text { part-time work }\end{array}$} & \multicolumn{2}{|c|}{$\begin{array}{l}\text { Wage differential } \\
\text { part-time/full-time }\end{array}$} \\
\hline & Males & Females & Males & Females \\
\hline Spain & 0.087 & 0.277 & $-0.104 * * *$ & $-0.254 * * *$ \\
\hline Andalusia & 0.089 & 0.296 & $-0.164 * * *$ & $-0.305 * * *$ \\
\hline Aragon & 0.063 & 0.261 & 0.028 & $-0.146 * * *$ \\
\hline Asturias & 0.054 & 0.213 & 0.028 & $-0.165 * * *$ \\
\hline Balearic Islands & 0.071 & 0.220 & -0.010 & $-0.192 * * *$ \\
\hline Canary Islands & 0.111 & 0.231 & $-0.139 * * *$ & $-0.268 * * *$ \\
\hline Cantabria & 0.058 & 0.233 & 0.050 & $-0.230 * * *$ \\
\hline Castilla-Leon & 0.061 & 0.252 & -0.016 & $-0.246 * * *$ \\
\hline Castilla La Mancha & 0.064 & 0.279 & -0.032 & $-0.269 * * *$ \\
\hline Catalonia & 0.079 & 0.235 & $-0.151 * * *$ & $-0.247 * * *$ \\
\hline Valencia & 0.099 & 0.306 & $-0.138 * * *$ & $-0.209 * * *$ \\
\hline Extremadura & 0.069 & 0.273 & $-0.098 * *$ & $-0.315 * * *$ \\
\hline Galicia & 0.067 & 0.226 & 0.045 & $-0.192 * * *$ \\
\hline Madrid & 0.073 & 0.208 & $-0.299 * * *$ & $-0.314 * * *$ \\
\hline Murcia & 0.090 & 0.286 & $-0.125 * * *$ & $-0.271 * * *$ \\
\hline Navarre & 0.063 & 0.314 & 0.049 & $-0.071 * * *$ \\
\hline Basque Country & 0.058 & 0.306 & 0.037 & $-0.227 * * *$ \\
\hline The Rioja & 0.068 & 0.290 & $-0.083^{*}$ & $-0.100 * * *$ \\
\hline Unweighted average & 0.073 & 0.261 & -0.060 & -0.222 \\
\hline Regional standard deviation & 0.016 & 0.036 & 0.100 & 0.071 \\
\hline Maximum & 0.111 & 0.314 & 0.050 & -0.071 \\
\hline Minimum & 0.054 & 0.208 & -0.299 & -0.315 \\
\hline
\end{tabular}

Notes: The incidence of part-time work is measured over total employees whereas the wage gap corresponds to the differential of the logarithm of the hourly wage between part- and full-time workers. Average unemployment rates for 2010 have been obtained from the Labour Force Survey.

$* p<0,1 ; * * p<0,05 ; * * * p<0,01$ 
Table 2.

Decomposition of the differential in average wages between part- and full-time workers.

Juhn-Murphy-Pierce decomposition.

\begin{tabular}{|c|c|c|c|c|c|c|c|c|}
\hline & Males & & & & Females & & & \\
\hline & Model 1 & Model 2 & Model 3 & Model 4 & Model 1 & Model 2 & Model 3 & Model 4 \\
\hline \multirow[t]{2}{*}{ Wage differential } & $-0.104 * * *$ & $-0.104 * * *$ & $-0.104 * * *$ & $-0.104 * * *$ & $-0.254 * * *$ & $-0.254 * * *$ & $-0.254 * * *$ & $-0.254 * * *$ \\
\hline & $0.002(-2.0)$ & - & & - & - & - & & \\
\hline Characteristics (1) & & $0.069(66.3)^{* * *}$ & $-0.088 * * *(84.6)$ & $0.032 * * *(30.8)$ & $0.104 * * *(40.9)$ & $0.208(81.9 * * *)$ & $-0.229 * * *(90.2)$ & $-0.144(56.7)$ \\
\hline Nationality & $-0.003 * * *$ & $-0.001 * * *$ & $-0.001 * * *$ & 0.000 & $-0.002 * * *$ & 0.000 & 0.000 & 0.001 \\
\hline Educational attainment & $-0.026 * * *$ & $-0.022 * * *$ & $-0.009 * * *$ & $-0.012 * * *$ & $-0.104 * * *$ & $-0.088 * * *$ & $-0.030 * * *$ & $-0.052 * * *$ \\
\hline Age & $0.031 * * *$ & $0.014 * * *$ & $0.011 * * *$ & $0.010 * * *$ & 0.001 & 0.000 & 0.000 & 0.000 \\
\hline Tenure & - & $-0.016 * * *$ & $-0.014 * * *$ & $-0.014 * * *$ & - & $-0.048 * * *$ & $-0.039 * * *$ & $-0.031 * * *$ \\
\hline Type of contract & - & $-0.016 * * *$ & $-0.007 * * *$ & $-0.005 * * *$ & - & 0.000 & 0.000 & 0.000 \\
\hline Occupation & - & - & $-0.053 * * *$ & $-0.012 * * *$ & - & - & $-0.116^{* * *}$ & $-0.062 * * *$ \\
\hline Region & - & $0.007 * * *$ & $0.006 * * *$ & - & - & $-0.005 * * *$ & $-0.002 * * *$ & - \\
\hline Industry of activity & - & $-0.040 * * *$ & $-0.029 * * *$ & - & - & $-0.052 * * *$ & $-0.029 * * *$ & - \\
\hline Firm size & - & $0.003 * * *$ & $0.003 * * *$ & - & - & $-0.006 * * *$ & $-0.006^{* * *}$ & - \\
\hline Collective agreement & - & $0.003 * * *$ & $0.002 * * *$ & - & - & $-0.010 * * *$ & $-0.006 * * *$ & - \\
\hline \multirow[t]{2}{*}{ Firm fixed effects (2) } & - & & & - & - & & & - \\
\hline & & - & - & $0.072 * * *(69.2)$ & & - & - & $0.108 * * *(42.5)$ \\
\hline Wage residuals (3) & $\frac{-}{0.106^{* * *}(102.0)}$ & 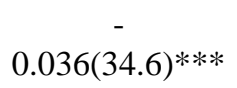 & $-0.016 * * *(15.4)$ & $0.000(0.0)$ & $0.150(59.1 * * *)$ & $\begin{array}{c}- \\
0.046(18.1)^{* * *}\end{array}$ & $-0.024 * * *(9.8)$ & $-0.002(0.8)$ \\
\hline Number of observations & 89,334 & 89,334 & 89,334 & 89,334 & 62,755 & 62,755 & 62,755 & 62,755 \\
\hline
\end{tabular}

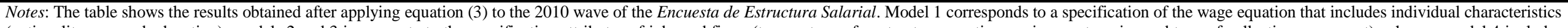

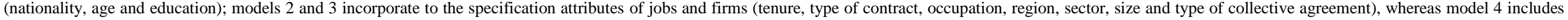
individual and job attributes and firm fixed effects instead of firm attributes. The percentage of the wage differential explained by each term appears in brackets.

$* p<0,1 ; * * p<0,05 ; * * * p<0,01$ 
Table 3.

Decomposition of the differential in average wages between part- and full-time workers. Juhn-Murphy-Pierce decomposition. Regional disaggregated analysis.

\begin{tabular}{|c|c|c|c|c|c|}
\hline & $\begin{array}{c}\text { Wage } \\
\text { differential }\end{array}$ & Characteristics (1) & $\begin{array}{l}\text { Firm fixed } \\
\text { effects (2) }\end{array}$ & $\begin{array}{c}\text { Wage } \\
\text { residuals (3) }\end{array}$ & $\begin{array}{l}\text { Number } \\
\text { of observ. }\end{array}$ \\
\hline \multicolumn{6}{|l|}{ Males } \\
\hline Andalusia & $-0.164 * * *$ & $-0.041 * *$ & $-0.123 * * *$ & -0.002 & 8,973 \\
\hline Aragon & 0.028 & $0.075 * * *$ & $-0.062 * * *$ & 0.015 & 3,747 \\
\hline Asturias & 0.028 & 0.030 & $-0.019 * * *$ & 0.017 & 2,971 \\
\hline Balearic Islands & -0.010 & -0.011 & -0.005 & 0.006 & 2,316 \\
\hline Canary Islands & $-0.139 * * *$ & $-0.035 * *$ & $-0.109 * * *$ & 0.005 & 3,69 \\
\hline Cantabria & 0.050 & $0.056 * * *$ & $-0.033 * * *$ & 0.026 & 2,385 \\
\hline Castilla-Leon & -0.016 & 0.020 & $-0.054 * * *$ & 0.017 & 4,781 \\
\hline Castilla La Mancha & -0.032 & 0.021 & $-0.029 * * *$ & -0.024 & 3,68 \\
\hline Catalonia & $-0.151 * * *$ & $-0.074 * * *$ & $-0.084 * * *$ & 0.006 & 14,763 \\
\hline Valencia & $-0.138 * * *$ & -0.014 & $-0.114 * * *$ & -0.009 & 7,389 \\
\hline Extremadura & $-0.098 * *$ & -0.019 & $-0.075 * * *$ & -0.004 & 2,042 \\
\hline Galicia & 0.045 & 0.000 & 0.005 & $0.039 * * *$ & 4,803 \\
\hline Madrid & $-0.299 * * *$ & $-0.141 * * *$ & $-0.125 * * *$ & $-0.034 * *$ & 15,32 \\
\hline Murcia & $-0.125 * * *$ & $-0.041 *$ & $-0.091 * * *$ & 0.007 & 2,764 \\
\hline Navarre & 0.049 & 0.002 & -0.017 & $0.064 * * *$ & 2,635 \\
\hline Basque Country & 0.037 & 0.007 & -0.007 & $0.036 * *$ & 5,69 \\
\hline The Rioja & -0.083 & -0.008 & $-0.050 * * *$ & -0.026 & 1,395 \\
\hline \multicolumn{6}{|l|}{ Females } \\
\hline Andalusia & $-0.305 * * *$ & $-0.149 * * *$ & $-0.156 * * *$ & -0.002 & 5,975 \\
\hline Aragon & $-0.146^{* * *}$ & $-0.119 * * *$ & $-0.059 * * *$ & $0.032 * *$ & 2,345 \\
\hline Asturias & $-0.165^{* * *}$ & $-0.151 * * *$ & -0.021 & 0.007 & 1,561 \\
\hline Balearic Islands & $-0.192 * * *$ & $-0.121 * * *$ & $-0.064 * * *$ & -0.007 & 1,807 \\
\hline Canary Islands & $-0.268 * * *$ & $-0.142 * * *$ & $-0.151 * * *$ & 0.025 & 2,685 \\
\hline Cantabria & $-0.230 * * *$ & $-0.119 * * *$ & $-0.104 * * *$ & -0.008 & 1,229 \\
\hline Castilla-Leon & $-0.246 * * *$ & $-0.124 * * *$ & $-0.123 * * *$ & -0.001 & 3,117 \\
\hline Castilla La Mancha & $-0.269 * * *$ & $-0.133 * * *$ & $-0.137 * * *$ & 0.002 & 2,166 \\
\hline Catalonia & $-0.247 * * *$ & $-0.139 * * *$ & $-0.096 * * *$ & -0.012 & 12,362 \\
\hline Valencia & $-0.209 * * *$ & $-0.125 * * *$ & $-0.086 * * *$ & 0.002 & 4,83 \\
\hline Extremadura & $-0.315^{* * *}$ & $-0.155 * * *$ & $-0.155^{* * *}$ & -0.005 & 1,063 \\
\hline Galicia & $-0.192 * * *$ & $-0.123 * * *$ & $-0.087 * * *$ & 0.018 & 3,505 \\
\hline Madrid & $-0.314 * * *$ & $-0.179 * * *$ & $-0.121 * * *$ & -0.014 & 13,062 \\
\hline Murcia & $-0.271 * * *$ & $-0.139 * * *$ & $-0.130 * * *$ & -0.002 & 1,634 \\
\hline Navarre & $-0.071 * * *$ & $-0.097 * * *$ & -0.007 & $0.033 * *$ & 1,265 \\
\hline Basque Country & $-0.227 * * *$ & $-0.147 * * *$ & $-0.079 * * *$ & -0.001 & 3,392 \\
\hline The Rioja & $-0.100 * * *$ & $-0.112 * * *$ & 0.005 & 0.008 & 757 \\
\hline
\end{tabular}


Table A.1. Recent studies about part-time versus full-time wage differences

\begin{tabular}{|c|c|c|c|c|c|c|c|c|c|}
\hline Authors & Country & Years & Databases & Samples/Gender & Sample/Age & $\begin{array}{c}\text { Part-time wage } \\
\text { penalty }\end{array}$ & $\begin{array}{c}\begin{array}{c}\text { Control } \\
\text { occupations }\end{array} \\
\end{array}$ & Control self-selection & $\begin{array}{c}\begin{array}{c}\text { Firm Fixed } \\
\text { Effects }\end{array} \\
\end{array}$ \\
\hline $\begin{array}{l}\text { O'Connell and Gash } \\
\text { (2003) }\end{array}$ & Ireland & 1994 & ECHP & Men and Women & 17 and more & $\begin{array}{ll}\text { M } & 0 \% \\
\text { W } & -9 \% * \\
\text { M } & 0 \% \\
\text { W } & 0 \%\end{array}$ & $\begin{array}{l}\text { No } \\
\text { No } \\
\text { Yes } \\
\text { Yes }\end{array}$ & $\begin{array}{l}\text { No } \\
\text { No } \\
\text { No } \\
\text { No }\end{array}$ & $\begin{array}{l}\text { No } \\
\text { No } \\
\text { No } \\
\text { No }\end{array}$ \\
\hline Hu and Tijdens (2003) & $\begin{array}{l}\text { Netherland and } \\
\text { Unites Kingdom }\end{array}$ & $1984-88$ & ECHP & $\begin{array}{c}\text { Men +Women } \\
\text { together }\end{array}$ & $15-65$ & $\begin{array}{ll}\text { Neth. } & -11 \% * \\
\text { UK } & -3 \% \%^{*} \\
\end{array}$ & Yes & Ordered Probit & No \\
\hline Rodgers (2004) & Australia & 2001 & $\begin{array}{c}\text { HILDA } \\
\text { (households) }\end{array}$ & Men and Women & $\ldots$ & $\begin{array}{ll}\text { M } & -3 \text { p. log. } \\
\text { W } & -9 \text { p. log. } \\
\end{array}$ & Yes & Multinomial Logit & No \\
\hline Hirsch (2005) & USA & 1995-2002 & $\begin{array}{c}\text { Census } \\
\text { Population } \\
\text { Survey }\end{array}$ & Men and Women & 16 and more & $\begin{array}{l}\text { M }-33 \text { p. log.* } \\
\text { W }-18 \text { p. log.* } \\
\text { M }-22 \text { p. log.* } \\
\text { W }-10 \text { p. log.* } \\
\text { M }+19 \text { p. log.* } \\
\text { W }+15 \text { p. log.* }\end{array}$ & $\begin{array}{l}\text { No } \\
\text { No } \\
\text { Yes } \\
\text { Yes } \\
\text { Yes } \\
\text { Yes } \\
\end{array}$ & $\begin{array}{c}\text { No } \\
\text { No } \\
\text { No } \\
\text { No } \\
\text { FE individual } \\
\text { FE individual } \\
\end{array}$ & $\begin{array}{l}\text { No } \\
\text { No } \\
\text { No } \\
\text { No } \\
\text { No } \\
\text { No } \\
\end{array}$ \\
\hline Jepsen et al (2005) & Belgium & 1995 & SES (firms) & Women & $\ldots$ & $\begin{array}{l}-4 \text { p. log.* } \\
+1 \text { p. log. } \\
\end{array}$ & $\begin{array}{l}\text { No } \\
\text { Yes } \\
\end{array}$ & $\begin{array}{l}\text { No } \\
\text { No } \\
\end{array}$ & $\begin{array}{l}\text { No } \\
\text { No }\end{array}$ \\
\hline Pissarides et al (2005) & $\begin{array}{c}\text { United Kingdom } \\
\text { Finland } \\
\text { Denmark } \\
\text { Germany } \\
\text { Netherland } \\
\text { Belgium } \\
\text { Austria } \\
\text { Ireland } \\
\text { France } \\
\text { Italy } \\
\text { Spain } \\
\text { Portugal } \\
\text { Greece }\end{array}$ & 1994-99 & ECHP & Men and Women & $16-61$ & 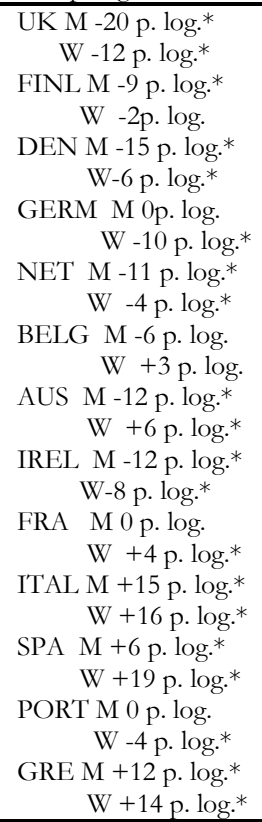 & Yes & No (1) & No \\
\hline
\end{tabular}


Table A.1. Recent studies about part-time versus full-time wage differences (cont')

\begin{tabular}{|c|c|c|c|c|c|c|c|c|c|}
\hline Authors & Country & Years & Databases & Samples/Gender & Sample/Age & $\begin{array}{l}\text { Part-time wage } \\
\text { penalty }\end{array}$ & $\begin{array}{c}\text { Control } \\
\text { occupations }\end{array}$ & Control self-selection & $\begin{array}{l}\text { Firm Fixed } \\
\text { Effects }\end{array}$ \\
\hline $\begin{array}{l}\text { Hardoy and Schone } \\
(2006)\end{array}$ & Norway & $1997-98$ & LLS (households) & $\begin{array}{l}\text { Women (only } \\
\text { voluntary PT) }\end{array}$ & $20-60$ & $\begin{array}{l}-0,5 \% \\
-10,9 \% \%^{*}\end{array}$ & $\begin{array}{l}\text { Yes } \\
\text { Yes }\end{array}$ & $\begin{array}{c}\text { No } \\
\text { Probit }\end{array}$ & $\begin{array}{l}\text { No } \\
\text { No }\end{array}$ \\
\hline O'Dorchai et al (2007) & $\begin{array}{c}\text { Belgium } \\
\text { Denmark } \\
\text { Italy } \\
\text { Spain } \\
\text { Ireland } \\
\text { United Kingdom } \\
\end{array}$ & 1995 & SES (firms) & Men & $\ldots$ & $\begin{array}{ll}\text { BEL } & -7 \text { p. log.* } \\
\text { DEN } & +1 \text { p. log. } \\
\text { ITA } & -13 \text { p. log.* } \\
\text { SPA } & -6 \text { p. log.* } \\
\text { IREL } & -29 \text { p. log.* } \\
\text { U K } & -15 \text { p. log.* }\end{array}$ & Yes & No & No \\
\hline Posel and Muller (2007) & South Africa & 2001-2004 & LFS (households) & Men & $\ldots$ & $\begin{array}{l}+34 \% * \\
+40 \% * \\
+50 \% *\end{array}$ & $\begin{array}{l}\text { No } \\
\text { Yes } \\
\text { Yes }\end{array}$ & $\begin{array}{c}\text { No } \\
\text { No } \\
\text { Individual FE }\end{array}$ & $\begin{array}{l}\text { No } \\
\text { No } \\
\text { No }\end{array}$ \\
\hline Pagán (2007) & Spain & 2000 & ECHP & Men and Women & $16-64$ & $\begin{array}{l}\text { M +6 p. log.* } \\
\text { W +14 p. log.* }\end{array}$ & Yes & Ordered Probit & No \\
\hline Russo and Massik (2008) & Netherland & $\begin{array}{c}1997-98 \\
\text { and } 1999- \\
2000\end{array}$ & WCS (firms) & $\begin{array}{l}\text { Men and Women } \\
\text { which do not } \\
\text { change company }\end{array}$ & $\ldots$ & $\begin{array}{ll}\mathrm{M} & -3 \% \%^{*} \\
\mathrm{~W} & -1 \% *\end{array}$ & Yesi & No & No \\
\hline $\begin{array}{l}\text { Manning and Petrongolo } \\
\text { (2008) }\end{array}$ & United Kingdom & $2001-03$ & LFS (households) & Women & $16-64$ & $\begin{array}{l}-11 \text { p. log.* } \\
-3 \text { p. log.* } \\
-11 \text { p. log.* } \\
-2 \text { p. log. } *\end{array}$ & $\begin{array}{l}\text { No } \\
\text { Yes } \\
\text { No } \\
\text { Yes } \\
\end{array}$ & $\begin{array}{c}\text { No } \\
\text { No } \\
\text { Probit } \\
\text { Probit } \\
\end{array}$ & $\begin{array}{l}\text { No } \\
\text { No } \\
\text { No } \\
\text { No }\end{array}$ \\
\hline $\begin{array}{l}\text { Mumford and Smith } \\
\text { (2008) }\end{array}$ & United Kingdom & 2004 & BWERS (firms) & Men and Women & $\ldots$ & $\begin{array}{lc}\mathrm{M} & 0 \text { p. } \log . \\
\mathrm{W} & -11 \text { p. log.* } \\
\mathrm{M} & +5 \text { p. log.* } \\
\mathrm{W} & -3 \text { p. log.* } \\
\mathrm{M} & +1 \text { p. log.* } \\
\mathrm{W} & -8 \text { p. log.* }\end{array}$ & $\begin{array}{l}\text { No } \\
\text { No } \\
\text { Yes } \\
\text { Yes } \\
\text { Yes } \\
\text { Yes }\end{array}$ & $\begin{array}{l}\text { No } \\
\text { No } \\
\text { No } \\
\text { No } \\
\text { No } \\
\text { No }\end{array}$ & $\begin{array}{l}\text { No } \\
\text { No } \\
\text { No } \\
\text { No } \\
\text { Yes } \\
\text { Yes }\end{array}$ \\
\hline $\begin{array}{l}\text { Bardasi and Gornick } \\
\text { (2008) }\end{array}$ & $\begin{array}{c}\text { Canada } \\
\text { USA } \\
\text { United Kingdom } \\
\text { Germany } \\
\text { Italy } \\
\text { Sweden } \\
\end{array}$ & 1994-1995 & $\begin{array}{l}\text { Luxembourg } \\
\text { Income Study }\end{array}$ & Women & $25-59$ & $\begin{array}{ll}\text { CAN } & -9 \text { p. log.* } \\
\text { USA } & -17 \text { p. log.* } \\
\text { UK } & -1 \text { p. log. } \\
\text { GER } & -8 \text { p. log.* } \\
\text { ITA } & -15 \text { p. log.* } \\
\text { SWE } & -3 \text { p. log.* } \\
\end{array}$ & Yes & Yes & No \\
\hline Boot and Wood (2008) & Australia & $2001-04$ & $\begin{array}{c}\text { HILDA } \\
\text { (households) }\end{array}$ & Men and Women & $18-60$ & $\begin{array}{l}\text { M Casual }+10 \%^{*} \\
\text { M No Cas }+15 \%^{*} \\
\text { W Casual }+15 \%^{*} \\
\text { W No Cas }+10 \% \%^{*}\end{array}$ & Yes & $\begin{array}{l}\text { Individual FE } \\
\end{array}$ & No \\
\hline $\begin{array}{l}\text { Connelly and Gregory } \\
(2009)\end{array}$ & United Kingdom & 1975-2001 & $\begin{array}{l}\text { New Earnings } \\
\text { Survey }\end{array}$ & Women & 16 and more & $\begin{array}{l}-10 \text { p. log.* } \\
-2 \text { p. log.* } \\
-7 \text { p. log.* } \\
-32 \text { p. log.* }\end{array}$ & $\begin{array}{l}\text { No } \\
\text { Yes } \\
\text { Yes } \\
\text { No }\end{array}$ & $\begin{array}{c}\text { Individual FE } \\
\text { Individual FE } \\
\text { Movers FE } \\
\text { Movers FE } \\
\end{array}$ & $\begin{array}{l}\text { No } \\
\text { No } \\
\text { No } \\
\text { No }\end{array}$ \\
\hline $\begin{array}{l}\text { Fernández-Kranz and } \\
\text { Rodríguez-Planas (2011) }\end{array}$ & Spain & 1996-2006 & MCVL & Women & $25-45$ & $\begin{array}{l}-19 \text { p. log.* } \\
-17 \text { p. log.* } \\
-13 \text { p. log.* } \\
-11 \text { p. log.* }\end{array}$ & $\begin{array}{l}\text { No } \\
\text { Yes } \\
\text { No } \\
\text { Yes }\end{array}$ & $\begin{array}{l}\text { Individual FE } \\
\text { Individual FE } \\
\text { Individual FE } \\
\text { Individual FE }\end{array}$ & $\begin{array}{l}\text { No } \\
\text { No } \\
\text { Yes } \\
\text { Yes }\end{array}$ \\
\hline
\end{tabular}


Table A.1. Recent studies about part-time versus full-time wage differences (cont')

\begin{tabular}{|c|c|c|c|c|c|c|c|c|c|}
\hline Authors & Country & Years & Databases & Samples/Gender & Sample/Age & $\begin{array}{c}\begin{array}{c}\text { Part-time wage } \\
\text { penalty }\end{array} \\
\end{array}$ & $\begin{array}{c}\text { Control } \\
\text { occupations }\end{array}$ & Control self-selection & $\begin{array}{c}\text { Firm Fixed } \\
\text { Effects }\end{array}$ \\
\hline $\begin{array}{l}\text { Fernández-Kranz, Paul } \\
\text { and Rodríguez-Planas } \\
\text { (2014) }\end{array}$ & Spain & $1996-2006$ & MCVL & Women & $23-45$ & $\begin{array}{l}\text { Permanent Contract } \\
-6 \text { p. log.* } \\
\text { Temporary Contract } \\
-9 \text { p. log.* }\end{array}$ & No (2) & $\begin{array}{c}\text { Multiequational Model } \\
\text { and Probit }\end{array}$ & Yes \\
\hline Wolf (2014) & $\begin{array}{c}\text { Germany } \\
\text { (East and West) }\end{array}$ & $1984-2010$ & $\begin{array}{c}\text { SOEP } \\
\text { (households) }\end{array}$ & Men and Women & $20-60$ & $\begin{array}{c}\text { West } \mathrm{M}-12 \%^{*} \\
\mathrm{M}-11 \%^{*} \\
\mathrm{~W} 0 \% \\
\mathrm{~W}+1 \% \\
\text { East } \mathrm{M}-11 \%^{*} \\
\mathrm{M}-10 \%^{*} \\
\mathrm{~W}+1 \% \\
\mathrm{~W}+2 \% \\
\end{array}$ & $\begin{array}{l}\text { No } \\
\text { Yes } \\
\text { No } \\
\text { Yes } \\
\text { No } \\
\text { Yes } \\
\text { No } \\
\text { Yes } \\
\end{array}$ & Individual FE & No \\
\hline Preston and $\mathrm{Yu}(2015)$ & Australia & 2010 & $\begin{array}{c}\text { AWS } \\
\text { (households) }\end{array}$ & Men and Women & $\ldots$ & $\begin{array}{c}\text { M }-8,9 \text { p.log* } \\
\text { W }-1,1 \text { p. } \log ^{*} \\
\text { W Casual }+7,1 \% \%^{*}\end{array}$ & Yes & No & No \\
\hline
\end{tabular}

* Statistically significant at the usual levels (1\% or $5 \%$, depending on each paper).

(1) According to the authors, results are robust to controlling for self selection by a probit model or by individual fixed effect when they work with the sample of movers from full-time to part-time.

(2) Authors explain that they introduced additional controls (occupations and more) and results did not change. 
Table A.2. Descriptive statistics.

\begin{tabular}{|c|c|c|c|c|c|c|c|c|}
\hline & \multicolumn{4}{|c|}{ Males } & \multicolumn{4}{|c|}{ Females } \\
\hline & \multicolumn{2}{|c|}{ Full-time } & \multicolumn{2}{|c|}{ Part-time } & \multicolumn{2}{|c|}{ Full-time } & \multicolumn{2}{|c|}{ Part-time } \\
\hline & Average & SD & Average & $\mathrm{SD}$ & Average & $\mathrm{SD}$ & Average & $\mathrm{SD}$ \\
\hline Logarithm of hourly wage & 2.423 & 0.494 & 2.318 & 0.591 & 2.282 & 0.481 & 2.028 & 0.400 \\
\hline Immigrant & 0.065 & 0.247 & 0.093 & 0.297 & 0.051 & 0.222 & 0.080 & 0.271 \\
\hline Primary education & 0.183 & 0.387 & 0.233 & 0.423 & 0.102 & 0.303 & 0.200 & 0.400 \\
\hline Secondary education & 0.598 & 0.490 & 0.585 & 0.493 & 0.542 & 0.498 & 0.637 & 0.481 \\
\hline Tertiary education & 0.219 & 0.414 & 0.181 & 0.385 & 0.356 & 0.479 & 0.163 & 0.369 \\
\hline Age & 40.640 & 10.150 & 42.740 & 14.830 & 39.080 & 9.826 & 39.200 & 10.920 \\
\hline Tenure & 9.351 & 9.676 & 9.877 & 13.410 & 8.320 & 9.059 & 5.114 & 6.623 \\
\hline Fixed-term contract & 0.811 & 0.391 & 0.444 & 0.497 & 0.800 & 0.400 & 0.666 & 0.472 \\
\hline Unskilled occupations & 0.089 & 0.285 & 0.162 & 0.368 & 0.089 & 0.285 & 0.297 & 0.457 \\
\hline Semi-skilled occupations & 0.478 & 0.499 & 0.435 & 0.495 & 0.277 & 0.447 & 0.362 & 0.481 \\
\hline Skilled occupations & 0.432 & 0.445 & 0.402 & 0.490 & 0.634 & 0.482 & 0.341 & 0.474 \\
\hline Andalusia & 0.099 & 0.299 & 0.111 & 0.314 & 0.080 & 0.272 & 0.134 & 0.341 \\
\hline Aragon & 0.042 & 0.201 & 0.038 & 0.191 & 0.038 & 0.191 & 0.036 & 0.186 \\
\hline Asturias & 0.034 & 0.181 & 0.028 & 0.164 & 0.025 & 0.156 & 0.025 & 0.155 \\
\hline Balearics & 0.023 & 0.151 & 0.052 & 0.223 & 0.026 & 0.158 & 0.037 & 0.189 \\
\hline Canary Islands & 0.042 & 0.201 & 0.033 & 0.179 & 0.044 & 0.205 & 0.040 & 0.196 \\
\hline Cantabria & 0.027 & 0.161 & 0.026 & 0.158 & 0.018 & 0.135 & 0.023 & 0.149 \\
\hline Castilla-Leon & 0.054 & 0.227 & 0.045 & 0.208 & 0.048 & 0.213 & 0.055 & 0.228 \\
\hline Castilla La Mancha & 0.042 & 0.201 & 0.032 & 0.176 & 0.037 & 0.188 & 0.029 & 0.167 \\
\hline Catalonia & 0.163 & 0.369 & 0.187 & 0.390 & 0.201 & 0.401 & 0.187 & 0.390 \\
\hline Valencia & 0.083 & 0.275 & 0.084 & 0.278 & 0.076 & 0.265 & 0.080 & 0.271 \\
\hline Extremadura & 0.024 & 0.151 & 0.017 & 0.127 & 0.016 & 0.125 & 0.020 & 0.139 \\
\hline Galicia & 0.055 & 0.228 & 0.040 & 0.196 & 0.059 & 0.236 & 0.047 & 0.211 \\
\hline Madrid & 0.171 & 0.377 & 0.172 & 0.377 & 0.223 & 0.416 & 0.170 & 0.376 \\
\hline Murcia & 0.031 & 0.174 & 0.026 & 0.159 & 0.026 & 0.158 & 0.027 & 0.163 \\
\hline Navarre & 0.030 & 0.169 & 0.029 & 0.166 & 0.020 & 0.141 & 0.020 & 0.139 \\
\hline Basque Country & 0.063 & 0.243 & 0.068 & 0.252 & 0.052 & 0.222 & 0.060 & 0.237 \\
\hline The Rioja & 0.016 & 0.125 & 0.012 & 0.109 & 0.012 & 0.108 & 0.013 & 0.111 \\
\hline Industry & 0.424 & 0.494 & 0.288 & 0.453 & 0.220 & 0.414 & 0.093 & 0.291 \\
\hline Construction & 0.122 & 0.327 & 0.037 & 0.188 & 0.014 & 0.117 & 0.005 & 0.073 \\
\hline Services & 0.454 & 0.498 & 0.675 & 0.468 & 0.766 & 0.423 & 0.902 & 0.298 \\
\hline Firm size less than 10 & 0.105 & 0.307 & 0.138 & 0.345 & 0.085 & 0.280 & 0.123 & 0.329 \\
\hline Firm size $10-49$ & 0.238 & 0.426 & 0.195 & 0.396 & 0.171 & 0.377 & 0.153 & 0.360 \\
\hline Firm size 50-199 & 0.277 & 0.447 & 0.226 & 0.418 & 0.218 & 0.413 & 0.235 & 0.424 \\
\hline Firm size 500 or more & 0.380 & 0.485 & 0.441 & 0.497 & 0.525 & 0.499 & 0.489 & 0.500 \\
\hline National sectoral collective agreement & 0.286 & 0.452 & 0.282 & 0.450 & 0.349 & 0.477 & 0.304 & 0.460 \\
\hline Sub-national sectoral collective agreement & 0.416 & 0.493 & 0.388 & 0.487 & 0.303 & 0.460 & 0.458 & 0.498 \\
\hline Firm collective agreement & 0.299 & 0.458 & 0.329 & 0.470 & 0.348 & 0.476 & 0.238 & 0.426 \\
\hline Number of observations & \multicolumn{2}{|c|}{81,578} & \multicolumn{2}{|c|}{7,766} & \multicolumn{2}{|c|}{45,338} & \multicolumn{2}{|c|}{17,417} \\
\hline
\end{tabular}

